International Journal of Current Micro6iology and Applied Sciences ISSN: 2319-7706 Volume 5 Number 2(2016) pp. 449-458

\title{
Study of the Impact of Hepatitis D Virus Infection on Chronic Hepatitis B Virus Patients in Egypt
}

\author{
Mohamed Abdel-Hamid Ahmed ${ }^{1}$, MostafaSaleh Abdel-Motaleb Sheemy ${ }^{2}$, \\ Nagwa Sedky ${ }^{3}$, Gamal Esmat ${ }^{4}$ and Azza Abdul-Azim Gomaa ${ }^{*}$ \\ ${ }^{1}$ Medical Microbiology and Immunology Department, Faculty of Medicine, \\ Minia University, Egypt \\ ${ }^{2}$ Medical Microbiology and Immunology, Department, Faculty of Medicine, \\ Beni-Suef University, Egypt \\ ${ }^{3}$ Medical Microbiology and Immunology, Faculty of Medicine, Cairo University, Egypt \\ ${ }^{4}$ Tropical Medicine, Faculty of Medicine, Cairo University, Egypt \\ ${ }^{5}$ Medical Microbiology and Immunology Department, Faculty of Medicine, \\ Beni-Suef University, Egypt \\ *Corresponding author
}

\begin{tabular}{|c|c|}
\hline \multirow[b]{2}{*}{ Keywords } & A B S T R A C T \\
\hline & \multirow{13}{*}{$\begin{array}{l}\text { Hepatitis D virus (HDV) is a defectivevirus thatrequires the presence of } \\
\text { hepatitis B virus (HBV) for infection. It has been estimated that } \\
\text { approximately } 5 \% \text { of the global hepatitis B surface antigen (HBsAg) carriers } \\
\text { are also co-infected with HDV, leading to a total of } 10-15 \text { million HDV } \\
\text { carriers worldwide. In the current study, we investigated anti-HDV } \\
\text { seroprevalance, epidemiological features and effect of HDV on HBV } \\
\text { morbidity and presence ofHBe antigen markers among } 216 \mathrm{HBsAg} \\
\text { seropositive patients recruited from four hospitals in Egypt between October } \\
2009 \text { and October 2011. Anti-HDV assay was performed by enzyme } \\
\text { immunoassay (EIA). Then, the HDV seropositive patients were further } \\
\text { investigated for HBe antigen and antibody, HBV DNA and HBV } \\
\text { genotyping.Out of } 216 \mathrm{HBs} \text { Ag positive patients, } 32 \text { (14.8\%) were anti-HDV } \\
\text { positive. This study confirmed a declining trend in the prevalence of HDV } \\
\text { infection in Egypt. A suppressive effect of HDV on HBV replication was } \\
\text { suggested from the lower rate of detection of HBeAg (3.13\%), which is } \\
\text { indirectly proportional to viral replication, and the higher rate of detection of } \\
\text { HBeAb ( } 75 \% \text { ) in anti-HDV positive patients. }\end{array}$} \\
\hline & \\
\hline & \\
\hline 10 & \\
\hline & \\
\hline $\mathrm{HBeAb}$ & \\
\hline genotyning & \\
\hline rticl & \\
\hline & \\
\hline & \\
\hline & \\
\hline & \\
\hline & \\
\hline
\end{tabular}




\section{Introduction}

HDV is a defective virus that needs HBV as a helper virus (Asmah et al., 2014). Rizzetto and colleagues (1977) discovered HDV in the mid-1970s while they were trying to find out why some patients with HBV infection had more serious disease than others.

On electron microscopy, HDV appears as an enveloped, spherical particle of around 36 $\mathrm{nm}$ in diameter. The outer coat of the virion containing host lipids and the HBs Ags surrounds an inner nucleocapsid consisting of viral ribonucleoproteins (RNPs) with the genomic RNA and about 200 molecules of hepatitis D antigen (HDAg) per genome.HDV has the smallest RNA genome (about 1700 nucleotides) of all known animal viruses. However, it is comparable, although larger, to viroid RNAs, pathogenic agents of higher plants (Manesis et al., 2007). Replication of the HDV RNA is proposed to occur by a double rolling-circle mechanism, similar to that proposed for the replication of plant viroids and small satellite RNAs of some plant viruses (Taylor, 2014).

HBV infection is a global health problem, and over 350 million people around the world are chronic carriers of the virus. It has been estimated that approximately $5 \%$ of the global HBsAg carriers are also co-infected with HDV, leading to a total of 10-15 million HDV carriers worldwide (Farci and Niro, 2012). HDV appears to be endemic in the Middle East. A decline in the prevalence of both acute and chronic hepatitis D (CHD) has been observed worldwide (Mumtaz et al., 2005).

As HDV is enveloped by $\mathrm{HBs} \mathrm{Ag}$, ithas similar transmission routes to those of HBV, with percutaneous exposure being the most important one (Su et al., 2006). HDV must either coinfect or superinfect with $\mathrm{HBV}$ infection (Koytak et al., 2007).

The pathogenesis of HDV remains controversial. In the acute stage, HDAg or HDV RNA may be directly cytotoxic to hepatocytes. In the chronic stage, inflammatory cells surround infected hepatocytes, and various autoantibodies have been detected in the serum of patients with CHD, suggesting the possible involvement of immune reaction in HDV pathogenesis (Huang et al., 2009).

HDV is dominant over HBV in the majority of cases (Heidrich et al., 2013).Co-infection and superinfection with HDV suppresses HBV replication in patients and in model systems. About $70-90 \%$ of patients with HDV co-infection areHBeAg negative, and most have low serum HBV DNA (Sagnelli et al., 2000 and Zachou et al., 2010).

Currently, Diagnosis of HDV infection can be achieved indirectly based on the detection of antibodies against HDAg (anti-HD). But still the most reliable tool to diagnose HDV infection is based on highly sensitive molecular techniques, reverse transcriptionPCR (RT-PCR) (Koytak et al., 2007).

Till present, Interferon is the only therapy for chronic hepatitis D. Nucleos(t)ides analogues are not effective against the helper hepatitis B virus (Rizzetto, 2013). Compared to chronic hepatitis B or C, CHD treatment requires a higher dosage and a longer duration of treatment, and posttreatment relapses are common. In order to prevent the progression of CHD and its related morbidity and mortality, more effective treatments are needed (Hsieh et al., 2006).

HDV infection is distributed worldwide, although not uniformly, and it is estimated 
that $5 \%$ of HBsAg carriers are also infected with HDV, which signifies that there might be between 15 and 20 million HDV-infected individuals (Rizzetto and Ciancio, 2012). This is a very rough number because it lacks data from areas where HBV is highly prevalent and HDV is poorly studied. HDV is highly endemic in Mediterranean countries, the Middle East, northern parts of South America, and Central Africa(Radjef et al., 2004). HDV also has high prevalence in Turkey (Bahcecioglu et al., 2011), Central Asia (Tsatsralt-Od et al., 2005), and the Amazonian region of Western Brazil (Paraná et al., 2006).

Egyptian studies conducted in 1990s demonstrated HDV antibodies in $23.53 \%$ in patients with chronic HBV (Darwish et al., 1992 and el-Zimaity et al., 1993). A later study detected anti-HDV in $20 \%$ of $\mathrm{HBsAg}$ positive subjects (Saudy et al., 2003).

The aim of this work was to determine the prevalence of HDV infection among HBsAg positive individuals either chronic hepatitis B cases or carriers, the association between HDV infection and the presence of $\mathrm{HBe}$ antigen marker that indirectly indicates viral replication and the correlation between HDV infection and the morbidity of HBV infection.

\section{Materials and Methods}

\section{Study Population}

This study was conducted on 216 patients who were seropositive for HBsAg. These patients were recruited from: hepatology clinics in National Hepatology and Tropical Medicine Research Institute, Beni-Suef University Hospital, Beni-Suef Insurance Hospital, El-Kahera El-Fatimya Hospital and from the inventory of National Hepatology and Tropical Medicine Research
Institute during the period from October 2009 to October 2011.

\section{History and Clinical Examination}

History (in particular the history of blood transfusion, surgery, tooth extraction, wound sutures or intravenous drug use), demographic data (including sex, age and residence) and clinical data were obtained from All patients who were then subjected to thorough clinical examination(with stress on signs of chronic liver disease e.g.: jaundice, palmar erythema, spider naevi, lower limb edema, hepatomegaly, splenomegaly and ascites).

\section{Routine Laboratory Investigations}

The laboratory investigations has been done including, complete blood picture, aspartate transaminase (AST), alanine transaminase (ALT), serum bilirubin and prothrombin time.

\section{Hepatitis Markers Testing}

Total HDV antibodies were tested for in all patients [byEnzyme immunoassay (EIA),Diasorin Kit, Italy]. The thirty two patients (32/216) with positive HDV antibody were further investigated for $\mathrm{HBeAg}$ [by microparticle enzyme immunoassay (MEIA) technology, ABBOTT, Germany] andHBeAb(by MEIA technology, ABBOTT, Germany).

\section{HBV DNA Detection and Genotyping}

HBV DNA detectionqualitatively by PCR[DNA extraction was carried by QIAamp DNA Mini Kits (Qiagen, Santa Clarita, USA) and PCR was performed using primers (table 1 ) from the $S$ region of the HBV genome thenthe PCR products were electrophoresed on a agarose gel, 
stained with ethidium bromide and evaluated under UV light. The sizes of PCR products (540 bp) were estimated according to the migration pattern of DNA ladder (Pharmacia Biotech, Piscataway, NJ, USA)] and HBV genotyping[by Restriction fragment length polymorphism (RFLP), (Boehringer Mannheim, Germany) using the restriction enzymes (Tsp509I and HinfI) digestion (Lindh et al., 1997).

\section{Results and Discussion}

Patients' ages ranged from 18 to 65 years old, with mean age for anti-HDV positive patients $34.44 \pm 12.544$ years and for antiHDV negative patients was $29.46 \pm 11.42$ years. With regard to gender, 23(71.9\%) out of the 32 anti- HDV positive patients were males and $9(28.1 \%$ ) were females (Table 2 ).

In anti-HDV positive patients mean of both ALT and AST were significantly elevated ( $\mathrm{p}$-values $=0.017$ and $=0.006$ respectively) and mean platelet count and prothrombin concentration were significantly decreased as compared to anti-HDV negative patients (p-values $<0.01 \quad$ and 0.001 respectively)(Table 3 ).

HBV-DNA PCR was detected in $16 / 32$ $(50 \%)$ anti-HDV positive patients and in $81 / 151 \quad(53.6 \%)$ anti-HDV negative patients, a result that was statistically insignificant ( $\mathrm{p}$-value $=0.71)$ (figures 1\&2).Genotype D was the only genotype detected in HBV-HDV coinfected patients 16/16 (100\%)(Figure 3).

The results of $\mathrm{HBe}$ antigen and antibody showed that in the anti-HDV positive patients only one patient $(3.6 \%)$ was $\mathrm{HBe}$ $\mathrm{Ag}$ positive while 22 (75.9\%) were $\mathrm{HBe} \mathrm{Ab}$ positive and these were statistically significant (p-values $<0.01$ and 0.01 respectively).

\section{HDV prevalence}

The present study confirmed the declining trend in the prevalence of HDV infection in Egypt to $14.8 \%(32 / 216$ of the study group) with higher prevalence among older male patients.

This prevalence is relatively low compared with earlier Egyptian studies that demonstrated HDV antibodies in $23.53 \%$ (Darwish et al., 1992 and el-Zimaity et al., 1993) and 20\% (Saudy et al., 2003) of HBsAg positive subjects. Our results were in agreement with a study conducted by (Njoh and Zimmo, 1998) in Saudi Arabia in which $13.6 \%$ of HBV carriers $(n=81)$ were positive for anti-HDV.

This decrease in prevalence also in paralleled the declining trend in the prevalence of HDV infection witnessed in some other countries. In Italy, the prevalence of anti-HDV among $\mathrm{HBsAg}$ carriers with liver diseases decreased from $25 \%$ in 1983 to $14 \%$ in 1992 (Navascues et al., 1995) then toonly $8.3 \%$ in 1997 (Sagnelli et al., 1997). A similar decrease (from $15.1 \%$ in 1983 to $7.1 \%$ in 1992) has also been reported in Spain(Gaeta et al., 2000). In Taiwan, (Huo et al., 1997) reported a decrease in HDV infection from $23.7 \%$ in 1983 to $4.2 \%$ in 1995 . A matter that can be attributed to many factors including implementation of a national anti-HBV vaccination program, introduction and wide use of disposable needles for blood sampling and other medical purposes in high-risk populations (Mast, 2006).

\section{Effect of HDV On morbidity}

In our study,HDV infection was associated with increased morbidity in the form of elevated mean of ALT and AST (p-values 
$=0.017$ and $=0.006$ respectively) and reduced mean of platelet count and prothrombin concentration ( $\mathrm{p}$-values $<0.01$ and $=0.001$ respectively).

Similar results were shown in the published data by (Bahcecioglu et al., 2011) where ALT level was significantly elevated in chronic HDV patients (p-value $=0.028$ ). Similarly, in another study there were 96/169 (56.8\%) patients with raised ALT in HBV/HDV co-infection group as compared to $137 / 311$ (44\%) in HBV mono-infection, (p-value $=0.008)$ (Mumtazet al., 2011). However in another study ALT elevation was not significant in HDV-associated infection compared with $\mathrm{HBV}$ infection alone whether acute viral hepatitis $(\mathrm{P}=0.82)$ or chronic $(\mathrm{P}=0.77)$ (Saravanan et al., 2008).

\section{Effect of HDV on HBV Viremia and HBV Genotype Association}

In the present study, HBV-DNA, a direct marker of viral replication, was detected in a higher percentage of patients with $\mathrm{HBV}$ mono-infection $53.6 \% \quad(81 / 151)$ as compared to $\mathrm{HBV} / \mathrm{HDV}$ co-infection $50 \%$ (16/32). However this difference between both groups was statistically insignificant ( $\mathrm{p}$-value $=0.71)$.

In the present study either HBV infected patients with or without HDV infection had lower percentage of HBV viremia than in other published data worldwide. This may be due to the high rate of spontaneous clearance of $\mathrm{HBV}$ in our region.

The obtained results are in contradiction with the data reported by Heidrich et al. (2012) suggesting suppressive effects of HDV on HBV irrespective to the phase of HBV infection. Moreover, in the study conducted by Mumtaz et al. (2011)they concluded that among $\mathrm{HBV} / \mathrm{HDV}$ coinfection, 146/169 (86.4\%) had suppressed $\mathrm{HBV}$ as compared to 231/311 (74.3\%) patients with HBV mono-infection (p-value $=0.002$ ). In another study a significant lower proportion of HBV replication was found in patients with HDV co-infection: $68.5 \%$ as compared with $89.3 \%$ in patients infected with HBV alone (Popescu et al., 2013). Both the small HDV p24 protein as well as the large HDV p27 protein may repress the HBV enhancers' pIIEland pIIE2 and thereby inhibit HBV replication (Williams et al., 2009).

A number of possible factors could explain these results including disparity in the sample size between different studies, variation in the age groups studied, differences in the endemicity of HBV infection among geographical areas and virological features of patients (viral genotypes, mutants or coinfection with other viruses) (Albano et al., 1992 and Grob et al., 2000). Moreover, the sensitivity of the molecular biology techniques might clarify too(Palmer et al., 1996). Furthermore, molecular assays may be impaired by contamination problems causing false positive results in some studies or an inadequate detection limit causing false negative results in other studies (Haushofer et al 2004).

In our study, HDV-RNA was not tested for and so the detection of HDV antibody alone doesn't ensure active HDV replication or presence of the HBV repressor protein in patient's serum. In addition, HBV DNA determination was made by a qualitative assay; hence evaluation of the impact of HDV on HBV DNA viremia in the studied patients wasn't comprehensive. 
Table.1 The Sequences of Primers used for HBV DNA-PCR

\begin{tabular}{|l|l|l|l|}
\hline No & nt position & Type & Sequence \\
\hline P7 & $256-278$ & S & 5'-GTGGTGGACTTCTCTCAATTTTC-3' \\
\hline P8 & $796-776$ & AS & 5-CGGTA(A/T)AAAGGGACTCA(A/C)GAT-3' \\
\hline
\end{tabular}

Table.2 Demographic Characteristics in Relation to Anti-HDV Results in the Studied Patients

\begin{tabular}{|c|c|c|c|c|c|c|}
\hline \multicolumn{3}{|c|}{ HDV assay } & \multicolumn{2}{|c|}{ anti-HDV } & \multirow[b]{2}{*}{$\begin{array}{c}\text { Total } \\
(\mathrm{n}=216)\end{array}$} & \multirow[b]{2}{*}{$P$ value } \\
\hline \multicolumn{3}{|c|}{ Demographic data } & $\begin{array}{c}\text { Negative } \\
(\mathrm{n}=184)\end{array}$ & $\begin{array}{c}\text { Positive } \\
(\mathrm{n}=32)\end{array}$ & & \\
\hline \multirow[t]{2}{*}{ Sex } & Female & $\begin{array}{l}\text { Number } \\
(\%)\end{array}$ & $\begin{array}{r}25 \\
(13.6 \%) \\
\end{array}$ & $9(28.1 \%)$ & $34(15.7 \%)$ & $\begin{array}{l}0.037 \\
(\mathrm{~S})\end{array}$ \\
\hline & Male & $\begin{array}{l}\text { Number } \\
(\%)\end{array}$ & $\begin{array}{r}159 \\
(86.4 \%) \\
\end{array}$ & $\begin{array}{r}23 \\
(71.9 \%)\end{array}$ & $\begin{array}{r}182 \\
(84.3 \%) \\
\end{array}$ & \\
\hline Age & \multicolumn{2}{|c|}{$\begin{array}{l}\text { Mean } \\
(\mathrm{SD})\end{array}$} & $\begin{array}{r}29.46 \\
(11.420)\end{array}$ & $\begin{array}{r}34.44 \\
(12.544)\end{array}$ & & 0.026 \\
\hline
\end{tabular}

Table.3 Results of Routine Laboratory Investigations in Relation to Anti-HDV values in the Studied Patients

\begin{tabular}{|rr|r|r|r|r|}
\hline & anti-HDV & Number & Mean & Std. Deviation & P value \\
\hline ALT_40 & Positive & 32.00 & 53.35 & 44.26 & \\
& Negative & 182.00 & 33.17 & 26.11 & $\mathbf{0 . 0 1 7}$ (S) \\
\hline AST_40 & Positive & 22.00 & 44.58 & 18.00 & $\mathbf{0 . 0 0 6}$ (S) \\
& Negative & 102.00 & 31.88 & 19.50 & \\
\hline Tbil & Positive & 22.00 & .91 & 0.40 & 0.526 \\
& Negative & 96.00 & .84 & 0.45 & \\
\hline HGB & Positive & 22.00 & 12.73 & 2.81 & \\
& Negative & 76.00 & 13.34 & 1.63 & 0.339 \\
\hline RBC & Positive & 22.00 & 4.62 & 0.97 & 0.409 \\
& Negative & 70.00 & 4.79 & 0.82 & \\
\hline \multirow{2}{*}{ WBC } & Positive & 22.00 & 5.16 & 1.46 & 0.243 \\
& Negative & 76.00 & 5.72 & 2.06 & \\
\hline PLTs & Positive & 22.00 & 208.05 & 60.07 & $<\mathbf{0 . 0 1 ( S )}$ \\
& Negative & 76.00 & 255.18 & 50.48 & \\
\hline PC & Positive & 22.00 & 77.32 & 8.15 & $\mathbf{0 . 0 0 1}$ (S) \\
& Negative & 71.00 & 85.10 & 9.08 & \\
\hline
\end{tabular}

S=significant 
In the study done by Schaper et al. (2010) they investigated virological patterns longitudinally over a period of 4-8 years in a retrospective-prospective approach and determined quantitative levels of $\mathrm{HBV}$ DNA, HDV RNA, and HBsAg. Importantly, and in contrast to conclusions drawn from previous cross-sectional approaches, the authors demonstrated a high frequency of fluctuating activity of either one or even both viruses. They revealed HBV-DNA quantitatively in sera of $56.7 \%$ (21/37) of untreated chronic HDV patients. Consequently, HDV cannot necessarily be considered as the "dominant" virus based on a single determination and the role of $\mathrm{HBV}$ replication for the pathogenesis of liver disease in hepatitis D should not be underestimated (Wedemeyer, 2010).

In the present study, genotyping was carried out for all HBV DNA positive cases among the anti-HDV positive group (16/32) i.e. HBV/HDV coinfection. Results showed that genotype $\mathrm{D}$ was the only genotype detected 16/16 (100\%). These results came in accordance with previous Egyptian studies that reported the predominance of genotype D in Egypt (Saudy et al., 2003 and Zaky et al., 2010) both studies concluded that genotype D was the only genotype detected.

\section{Effect of HDV on HBe Ag and HBe Ab}

In the this study, there was a low rate of detection of HBeAg (3.6\%) (Pvalues $<0.01$ ), and a high rate of detection of $\mathrm{HBeAb}(75.9 \%)$ in anti-HDV positive patients ( $p$-values $=0.01$ ).

These results may be due to the fact that HBV type D has higher rates of precore and core mutations which might had lead to the absence of $\mathrm{HBeAg}$ in the majority of cases and that the higher rate of detection of
$\mathrm{HBeAb}$ might be elicited before mutation and $\mathrm{HBeAg}$ disappeared either due to the mutations or the suppressive effect of HDV or both.

Our results are compatible with the published data by (Ichimura et al., 1988). They concluded that, HBeAg clearance was observed in a significantly higher proportion of HDV-superinfected carriers18/28 (64.3\%) as compared with carriers without HDV infection 70/214 $(32.7 \%)$ (P-value < 0.005), suggesting that HDV superinfection can be considered as an inducer factor of $\mathrm{HBeAg}$ clearance in HBV carriers. In another supportive study, anti-HBe was found more often in the serum of the hepatitis D infected patients (68.4\%) (JelićandJelić, 1994).Similar results were reported by (Mumtaz et al., 2011).

The investigators found that a large proportion of the studied patients with HBV/HDV co-infection had HBeAg negative disease $75.7 \%$ (128/169) as compared to HBV mono-infected patients $60.5 \%(188 / 311)$ reproducing a statistically significant correlation ( $\mathrm{p}$-value $=0.001$ ). Also, in a cohort of 534 anti-HDV positive patients, HBeAg-positivity was detected in 71/534 patients (13.3\%) (Heidrich et al., 2012).

In contrast to our results and those obtained by the previous investigators, Saudy and coworkers (2003) conducted a study with somewhat different grouping criteria of their patients, reporting that $\mathrm{HBeAg}$ positivity was significantly higher in the carriers of anti-HDV positive without HDV-RNA group $100 \%(6 / 6)$ than the other two groups [the anti-HDV positive with HDV-RNA group 22\% (2/9) and the anti-HDV negative group 35\% (21/60)] (pvalue $<0.05)$. 
Possible explanations for this difference may be due the lower mutation rate in other HBV genotypes, difference in the cohort of the studies or due to the decrease in the specificity of $\mathrm{HBeAb}$ assay which had led to false positive results or decrease in the sensitivity of $\mathrm{HBeAg}$ assay which had led to false negative results but this is not our propable explanation since detection of $\mathrm{HBeAb}$ and HBeAg byMEIA technology (ABBOTT, Germany) is one of the good assays.

Another explanation may be that the trend of the disease in $\mathrm{HBeAg}$-positive patients with hepatitis $\mathrm{D}$ has not been well established (Amini et al., 2011).

\section{References}

Albano, A., Pianetti, A., Biffi, M.R., et al. 1992. Prevalence of anti-HCV in subjects of various age groups. Eur $\mathrm{J}$ Epidemiol. 8: 309-311.

Amini, N.,Alavian, S.M., Kabir, A., et al. 2011. Clinical Features and Seroepidemiology of Anti-HDV Antibody in patients With Chronic Hepatitis B Virus Infection in Iran: A Meta-Analysis. Hepat Mon. 11(12):960-967.

Asmah, R.H., Boamah, I.,Afodzinu, M., et al. 2014. Prevalence of hepatitis D infection in patients with hepatitis B virus-related liver diseases in Accra, Ghana. WestAfr J Med. 33(1):3236.

Bahcecioglu, I., Aygun, C., Gozel, N., et al. 2011.hepatitis B patients in eastern Turkey: still a Prevalence of hepatitis delta virus (HDV) infection in chronic serious problem to consider. Journal of Viral

Hepatitis.18(7):518-524. [PubMed]

Bahcecioglu, I.H., Aygun, C., Gozel, N., et al. 2011. Prevalence of hepatitis delta virus (HDV) infection in chronic hepatitis B patients in eastern Turkey: still a serious problem to consider. $\mathbf{J}$ Viral Hepat. 18(7):518-524.

Darwish, M.A., Shaker, M., Raslan, O.S. and Abdel-Raouf, T. 1992. Delta virus infection in Egypt. J Egypt Public Health Assoc.67 (1-2):147-161.

El-Zimaity, D.M., Hyams, K.C., Imam, I.Z., et al. 1993. Acute sporadic hepatitis E in an Egyptian pediatric population. Am J Trop Med Hyg. 48:372-376.

Farci, P.andNiro, G.A. 2012. Clinical features of hepatitis D. Semin Liver Dis.32(3):228-236.

Gaeta, G.B., Stroffolini, T., Chiaramonte, M. et al. 2000. Chronic hepatitis D: a vanishing disease? An Italian multicenter study.Hepatology. 32:824-827.

Grob, P., Jilg, W., Bornhak, H., et al. 2000. Serological pattern 'anti-HBc alone': report on a workshop. J Med Virol. 62: 450-455.

Haushofer, A.C., Hauer, R., Brunner, H., et al. 2004. No evidence of hepatitis B virus activity in patients with anti-HBc antibody positivity with or without antihepatitis $\mathrm{C}$ virus antibody positivity. $\mathrm{J}$ Clin Virol. 29(4): 221-223.

Heidrich, B., Manns, M.P.andWedemeyer, H. 2013.Treatment options for hepatitis delta virus infection.Curr Infect Dis Rep. 15(1):31-38.

Heidrich, B., Serrano, B.C., Idilman, R., et al. 2012.HBeAg-positive hepatitis delta: virological patterns and clinical long-term outcome. Liver Int. 32(9):1415-1425.

Hsieh, T.H., Liu, C.J., Chen, D.S. and Chen, P.J. 2006. Natural course and treatment of hepatitis D virus infection. J Formos Med Assoc. 105: 869-881.

Huang, C., Chang, S.C., Yang, H.C., et al. 2009. Clathrin-mediated post-Golgi membrane trafficking in the 
morphogenesis of hepatitis delta virus. J Virol. 83: 12314-12324.

Huo, T.I., Wu, J.C., Lin, R.Y., et al. 1997.Decreasing hepatitis D virus infection in Taiwan: an analysis of contributory factors. J GastroenterolHepatol.12: 747-751.

Ichimura, H., Tamura, I.,Tsubakio, T., et al. 1988. Influence of hepatitis delta virus superinfection on the clearance of hepatitis B virus (HBV) markers in HBV carriers in Japan. J Med Virol. 26(1):49-55.

Jelić, D.andJelić, O. 1994. The HBe antigen-antibody system and its relationship to epidemiological, histological and biochemical findings in patients with HBV+ HDV chronic liver diseases. Acta Med Croatica. 48(2):7783.

Koytak, E., Yurdaydin, C. and Glenn, J. 2007. Hepatitis D. Curr Treat Options Gastroenterol. 10(6):456-463.

Lindh, M., Andersson, A.S., Gusdal, A. 1997. Genotypes, nt 1858 Variants, and Geographic Origin of Hepatitis B Virus Large-Scale Analysis Using a New Genotyping Method. The Journal of Infectious Diseases. 175: 1285-1293

Manesis, E.K., Schina, M., Le Gal, F., et al. 2007. Quantitative analysis of hepatitis D virus RNA and hepatitis B surface antigen serum levels in chronic delta hepatitis improves treatment monitoring. AntivirTher. 12: 381-388.

Mast, E.E. 2006. Advisory Committee on Immunization Practices (ACIP) A comprehensive immunization strategy to eliminate transmission of hepatitis B virus infection in the United States. Centers for Disease Control. 54 (16): 131.

Mumtaz, K., Ahmed, U.S., Memon, S., et al. 2011. Virological and clinical characteristics of hepatitis delta virus in South Asia. Virol J. 20;8:312.
Mumtaz, K., Hamid, S., Adil, S., et al. 2005. Epidemiology and clinical pattern of hepatitis delta virus infection in Pakistan. J GastroenterolHepatol. 20: 1503-1507.

Navascues, C.A., Rodriguez, M., Sotorrio, N.G., et al. 1995. Epidemiology of hepatitis D virus infection: changes in the last 14 years. Am J Gastroenterol. 90: 1981-1984.

Njoh, J. and Zimmo, S. 1998. Prevalence of antibody to hepatitis D virus among HBsAg-positive drug-dependent patients in Jeddah, Saudi Arabia. East Afr Med J. 75:327-328.

Palmer, D.R., Perry, K.R., Mortimer, P.P., et al. 1996. Variation in the sensitivity of HBsAg screening kits. Transfus Med. 6(4): 311-317.

Paraná, R. Kay, A.Molinet, F., et al. 2006.HDV genotypes in the Western Brazilian Amazon region: a preliminary report. American Journal of Tropical Medicine and Hygiene. 75(3):475-479. [PubMed]

Popescu, G.A., Otelea, D., Gavriliu, L.C., et al. 2013. Epidemiology of hepatitis D in patients infected with hepatitis B virus in bucharest: A cross-sectional study.J Med Virol. 85(5):769-774.

Radjef, N., Gordien, E., Ivaniushina, V., et al. 2004.Molecular phylogenetic analyses indicate a wide and ancient radiation of african hepatitis delta virus, suggesting a Deltavirus genus of at least seven major clades. Journal of Virology.78 (5):2537-2544. [PMC free article] [PubMed]

Rizzetto, M. 2013.Current management of delta hepatitis. Liver Int. Suppl 1:195197.

Rizzetto, M., Canese, M.G., Aricò, S., et al. 1977. Immunofluorescence detection of new antigen-antibody system (delta/anti-delta) associated to hepatitis 
B virus in liver and in serum of $\mathrm{HBsAg}$ carriers. Gut .18: 997-1003.

Rizzetto, M., Ciancio, A. 2012.Epidemiology of hepatitis D. Seminars in Liver Disease. 32(3):211219.

Sagnelli, E., Coppola, N., Scolastico, C., et al. 2000.Virologic and clinical expressions of reciprocal inhibitory effect of hepatitis B, C, and delta viruses in patients with chronic hepatitis. Hepatology. 32: 1106-1110.

Sagnelli, E., Stroffolini, T., Ascione, A., et al. 1997. Decrease in HDV endemicity in Italy. J Hepatol. 26: 20-24.

Saravanan, S., Velu, V., Kumarasamy, N., et al. 2008. Seroprevalence of hepatitis delta virus infection among subjects with underlying hepatic diseases in Chennai, southern India. Trans R Soc Trop Med Hyg. 102(8):793-796.

Saudy, N., Sugauchi, F., Tanaka, Y., et al. 2003. Genotypes and phylogenetic characterization of hepatitis B and delta viruses in Egypt. J Med Virol. 70(4):529-536.

Schaper, M., Rodriguez-Frias, F., Jardi, R., et al. 2010. Quantitative longi-tudinal evaluation of hepatitis delta virus RNA and hepatitis B virus DNA shows a dynamic complex replicative profile in chronic hepatitis B and D. J Hepatol. 52:658-664

Su, C.W., Huang, Y.H.,Huo, T.I., et al. 2006. Genotypes and viremia of hepatitis B and D viruses are associated with outcomes of chronic hepatitis D patients. Gastroenterology.130: 16251635.

Taylor, J.M. 2014.Host RNA circles and the origin of hepatitis delta virus. World J Gastroenterol. 20(11):2971-2978.

Tsatsralt-Od, B., Takahashi, M., Nishizawa, T., et al. 2005.High prevalence of dual or triple infection of hepatitis B, C, and delta viruses among patients with chronic liver disease in Mongolia. Journal of Medical Virology. 77(4):491-499. [PubMed]

Wedemeyer, H. 2010. Re-emerging interest in hepatitis delta: new insights into the dynamic interplay between HBV and HDV. J Hepatol.52(5):627-629.

Williams, V., Brichler, S., Radjef, N., et al. 2009. Hepatitis delta virus proteins repress hepatitis B virus enhancers and activate the alpha/beta interferoninducible MxA gene. J Gen Virol.90:2759-2767.

Zachou, K., Yurdaydin, C., Drebber, U., et al. 2010.Quantitative HBsAg and HDV-RNA levels in chronic delta hepatitis. Liver Int. 30: 430-437.

Zaky, S., Farghaly, A.M., Rashed, H.A., et al. 2010.Clinicopathologic features and genotyping of patients with chronic HBV infection in the Upper Egypt. Cell Immunol. 265(2):97-104.

\section{How to cite this article:}

Mohamed Abdel-Hamid Ahmed, MostafaSaleh Abdel-Motaleb Sheemy, Nagwa Sedky, Gamal Esmat and Azza Abdul-Azim Gomaa. 2016. Study of the Impact of Hepatitis D Virus Infection on Chronic Hepatitis B Virus Patients in Egypt. Int.J.Curr.Microbiol.App.Sci. 5(2): 449-458. doi: http://dx.doi.org/10.20546/ijcmas.2016.502.050 